\title{
Effect of Different Treatments on Spawn Run Time of Paddy Straw
} Mushroom, Volvariella volvacea

\author{
Gaikwad Mahesh Balaso ${ }^{1 *}$, Krishan Kumar Mrig ${ }^{1}$, Surjeet Singh², \\ Challa Nalini ${ }^{3}$ and Panma Yankit ${ }^{3}$ \\ ${ }^{1}$ Department of Entomology, ${ }^{2}$ Department of Plant Pathology, Choudhary Charan Singh \\ Haryana Agricultural University, Hisar, Haryana, India \\ ${ }^{3}$ Department of Entomology, Dr YS Parmar University of Horticulture and Forestry, \\ Nauni, Solan, HP, India \\ *Corresponding author
}

\begin{abstract}
A B S T R A C T
Keywords

Paddy straw

mushroom,

Spawn run time,

Novaluron,

Chlorpyrifos,

Hot water

Article Info

Accepted:

12 February 2019

Available Online:

10 March 2019

The experiment laid out at mushroom production technology laboratory of Department of Plant Pathology, Haryana Agricultural University during August 2013 and April 2014. Paddy straw mushroom was raised by using standard production technology given by DMR, Solan. Total ten treatments and control replicated three times were evaluated for effect on spawn run time. The results showed that maximum time taken for spawn run time recorded in control, however minimum in Novaluron $10 \mathrm{EC}(0.5 \mathrm{ml} / \mathrm{l})$ which was

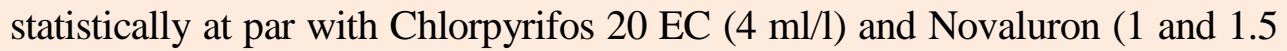
$\mathrm{ml} / \mathrm{l}$ ) treatment. All hot water treatments and different concentration of Novaluron significantly lower(less time) than control.

\section{Introduction}

About 200 types out of more than 3000 edible mushroom have been produced under controlled conditions all over world. India is home to more than 300 varieties of mushrooms found in the wild (Singh et al., 2018). The global mushroom production (in tonnes) ranks as per FAO Statistics-2016 was estimated i.e., China (7797929)>USA

(260140)>Netherlands (300000) >Polands (260140) and India (29992) (FAO, 2016). Paddy straw mushroom also called as tropical mushroom, is an edible mushroom of the tropics and subtropics, Volvariella mushrooms account for $7 \%$ of total production of cultivated mushrooms in the India (Sharma et al., 2017). In India this mushroom was first cultivated was the first to be cultivated in India as early as 1943 by Thomas and his
\end{abstract}


associates at Coimbatore. In India, nineteen edible species of Volvariella have been reported nevertheless most cultivation methods have been formulated only for three species namely, V. esculenta (Mass) Sing., $V$. diplasia (Berk and Br.) Sing. and $V$. volvacea (Bull. ex Fr.) Sing.(Singh et al., 2018).

Like most vegetables, mushrooms are a good source of minerals. $V$. volvacea is known to be rich in potassium, sodium and phosphorus and together with calcium and magnesium, these constitute 56 to $70 \%$ of the total ash content (Li and Chang, 1982). The approximate composition of fresh paddy straw mushroom $(100 \mathrm{~g})$ i.e., Moisture 90.40g $>$ Protein $3.90 \mathrm{~g}>$ Crude fibers $1.87 \mathrm{~g}>$ Ash $1.10 \mathrm{~g}>$ Fat $0.25 \mathrm{~g}>$ Ascorbic acid 18.00 (mg) >Calcium $5.60(\mathrm{mg})>$ Niacin $2.40(\mathrm{mg})>$ Iron $1.70(\mathrm{mg})$ $>$ Riboflavin $0.61(\mathrm{mg})>$ Potassium $0.32(\mathrm{mg})$ $>$ Thiamine $0.14(\mathrm{mg})>$ Phosphorus $0.10(\mathrm{mg})$ and Amino acid contents of paddy straw mushroom (mg/100g protein) i.e., Valine 6.8> Isoleucine 5.5> Phenyl alanine 4.9> Lysine 4.3> Threonine 4.2> Arginine 4.1> Leucine 3.5> Histidine 2.1> Tryptophane 1.1> Methionine 0.9 (Ahlawat et al.,2006; Ahlawat and Tewari, 2007). For the raising of this mushroom some chemicals and physical treatments were used for management of pest and diseases simultaneously, effect of these treatment on spawn run of mushroom need to study. These studies were carried out to study the effect of different chemicals, botanicals and physical treatments on spawn run time.

\section{Materials and Methods}

Paddy straw mushroom strain Vv-01 was cultivated under seasonal condition using standard packages of practices. The insecticides/ botanicals were added in the water used for wetting of substrate. The details of insecticides/botanicals treatments and their concentration used in the experiment are given in table 1.

\section{Insecticide treatment}

Four insecticides viz., Nimbecidine 300ppm at $5 \mathrm{ml}$, Achook 1500ppm at $4 \mathrm{ml}$, Novaluran 10 EC at $0.5,1.0$ and $1.5 \mathrm{ml}$ and Chlorpyrifos 4 $\mathrm{ml}$ per litre of water added at time of substrate wetting, paddy straw bundles were dipped in insecticides solution.

\section{Hot water treatment}

The bundles of paddy straw soaked in water and submerged in hot water at $80-90^{\circ} \mathrm{C}$ for 10 , 20, 30 minutes.

\section{Preparation of neem seed kernel extract}

Neem seed powder was prepared from field collected seeds of neem with the help of grinding machine. Powder was soaked in water overnight and strained through muslin cloth. Neem seed kernel extract $2 \mathrm{ml}$ per litre of water solution was prepared and paddy straw bundles were dipped in NSKE solution. Observation on time taken for spawn run were recorded by the visual basis observation when whole of bed was covered with mycelium.

\section{Data analysis}

Data were analysed by using the OPSTAT software of CCS, Haryana Agriculture University, Hisar, Haryana.

\section{Results and Discussion}

The data recorded during August 2013 (Table 1) revealed that the lowest spawn run time in case of novaluron 10 EC @ $0.5 \mathrm{ml}$ and chlorpyrifos 20 EC @ $4 \mathrm{ml}$ was 7.6 days as compared to control (10 days) which was at par with other treatments i.e. achook 1500 ppm @ 4 ml (8 days), nimbecidine 300ppm @ $5 \mathrm{ml}$ and hot water treatment at $80-90^{\circ} \mathrm{C}$ for 20 minutes (8.3 days), novaluron 10 EC @ $1.0 \mathrm{ml}$ and @ $1.5 \mathrm{ml}$ and hot water treatment at 80- 
$90^{\circ} \mathrm{C}$ for 10 minutes (8.6 days). Neem seed kernel extract at $2 \mathrm{ml}$ and hot water treatment at $80-90^{\circ} \mathrm{C}$ for 30 minutes had significantly more spawn run period of 9.6 and 9.3 days, respectively as compared to novaluron $10 \mathrm{EC}$ @ $0.5 \mathrm{ml}$ and chlorpyrifos $20 \mathrm{EC} @ 4 \mathrm{ml}(7.6$ days).

Novaluron 10 EC @ $0.5 \mathrm{ml}$ and chlorpyrifos 20 EC @ 4 ml (7.6 days), achook 1500 ppm @ $4 \mathrm{ml}$ (8 days), nimbecidine $300 \mathrm{ppm}$ @ 5 $\mathrm{ml}$ and hot water treatment at $80-90^{\circ} \mathrm{C}$ for 20 minutes (8.3 days), novaluron 10 EC @ $1.0 \mathrm{ml}$ and $1.5 \mathrm{ml}$ and hot water treatment at $80-90^{\circ} \mathrm{C}$ for 10 minutes (8.6 days) had significantly less spawn run time as compared to control which was at par with neem seed kernel extract $2 \mathrm{ml}$ (9.6 days) and hot water treatment at $80-90^{\circ} \mathrm{C}$ for 30 minutes ( 9.3 days). There was decrease in spawn run time of 2.4 days in both chlorpyrifos 20 EC @ $4 \mathrm{ml}$ and novaluron 10
EC @ $0.5 \mathrm{ml}$ and (1.7 days) in nimbecidine 300 ppm @ $5 \mathrm{ml}$ as compared to control.

During cropping period April 2014, the minimum (7.3 days) spawn run period was observed similar both in treatments of novaluron 10 EC @ $0.5 \mathrm{ml}$ and chlorpyrifos 20 EC @ $4 \mathrm{ml}$ while maximum was observed in control (9.6 days).

Whereas which was at par with other treatments i.e. achook 1500 ppm @ 4 ml, nimbecidine 300ppm @ $5 \mathrm{ml}$, hot water treatment at $80-90^{\circ} \mathrm{C}$ for 10 and 20 minutes (7.6 days), novaluron 10 EC @ $1.0 \mathrm{ml}(8.0$ days), novaluron 10 EC @ $1.5 \mathrm{ml}$ (8.3 days). Neem seed kernel extract at $2 \mathrm{ml}$ (9.3 days) and hot water treatment at $80-90^{\circ} \mathrm{C}$ for 30 minutes ( 9 days) had significantly more spawn run period as compared to novaluron 10 EC @ $0.5 \mathrm{ml}$ and chlorpyrifos $20 \mathrm{EC} 4 \mathrm{ml}$ (7.3 days).

Table.1 Effect of insecticides and hot water treatments on spawn-run period during August 2013, April 2014 and mean of season

\begin{tabular}{|c|c|c|c|c|c|c|c|}
\hline \multirow[t]{2}{*}{ Treatments } & \multirow[t]{2}{*}{ Dose } & \multicolumn{3}{|c|}{ Complete spawn run period (days) } & \multicolumn{3}{|c|}{$\begin{array}{l}\text { Increase (+) or decrease (-) } \\
\text { over control (days) }\end{array}$} \\
\hline & & 2013 & 2014 & Mean & 2013 & 2014 & Mean \\
\hline Nimbecidine (300ppm) & $5 \mathrm{ml} / 1$ & $8.3 \pm 0.50$ & $7.6 \pm 0.48$ & $8.0 \pm 0.49$ & -1.7 & -2.0 & -1.8 \\
\hline Achook (1500 ppm) & $4 \mathrm{ml} / \mathrm{l}$ & $8.0 \pm 0.52$ & $7.6 \pm 0.50$ & $7.8 \pm 0.51$ & -2.0 & -2.0 & -2.0 \\
\hline $\begin{array}{l}\text { Neem seed kernel } \\
\text { extracts }\end{array}$ & $2 \mathrm{ml} / \mathrm{l}$ & $9.6 \pm 0.62$ & $9.3 \pm 0.58$ & $9.5 \pm 0.62$ & -0.4 & -0.3 & -0.3 \\
\hline Novaluron (10 EC) & $0.5 \mathrm{ml} / \mathrm{l}$ & $7.6 \pm 0.48$ & $7.3 \pm 0.46$ & $7.5 \pm 0.45$ & -2.4 & -2.3 & -2.3 \\
\hline Novaluron (10 EC) & $1 \mathrm{ml} / \mathrm{l}$ & $8.6 \pm 0.53$ & $8.0 \pm 0.52$ & $8.3 \pm 0.55$ & -1.4 & -1.6 & -1.5 \\
\hline Novaluron (10 EC) & $1.5 \mathrm{ml} / 1$ & $8.6 \pm 0.56$ & $8.3 \pm 0.55$ & $8.5 \pm 0.56$ & -1.4 & -1.3 & -1.3 \\
\hline Chlorpyrifos (20 EC) & $4 \mathrm{ml} / \mathrm{l}$ & $7.6 \pm 0.48$ & $7.3 \pm 0.47$ & $7.5 \pm 0.47$ & -2.4 & -2.3 & -2.3 \\
\hline Hot water & $\begin{array}{l}80-90^{\circ} \mathrm{C} \text { for } 10 \\
\text { minutes }\end{array}$ & $8.6 \pm 0.59$ & $7.6 \pm 0.55$ & $8.1 \pm 0.57$ & -1.4 & -2.0 & -1.7 \\
\hline Hot water & $\begin{array}{l}80-90^{\circ} \mathrm{C} \text { for } 20 \\
\text { minutes }\end{array}$ & $8.3 \pm 0.47$ & $7.6 \pm 0.45$ & $8.0 \pm 0.46$ & -1.7 & -2.0 & -1.8 \\
\hline Hot water & $\begin{array}{l}80-90^{\circ} \mathrm{C} \text { for } 30 \\
\text { minutes }\end{array}$ & $9.3 \pm 0.56$ & $9.0 \pm 0.55$ & $9.1 \pm 0.55$ & -0.7 & -0.6 & -0.6 \\
\hline Control(Water) & & $10.0 \pm 0.52$ & $9.6 \pm 0.51$ & $9.8 \pm 0.51$ & & & \\
\hline $\begin{array}{l}\mathrm{SE}(\mathrm{m}) \\
\mathrm{CD}(\mathbf{P}=0.05)\end{array}$ & & $\begin{array}{l}0.49 \\
1.44\end{array}$ & $\begin{array}{l}0.46 \\
1.36\end{array}$ & $\begin{array}{l}0.48 \\
1.43\end{array}$ & & & \\
\hline
\end{tabular}


Fig.1 Effect of insecticides and hot water treatments on mean spawn-run period

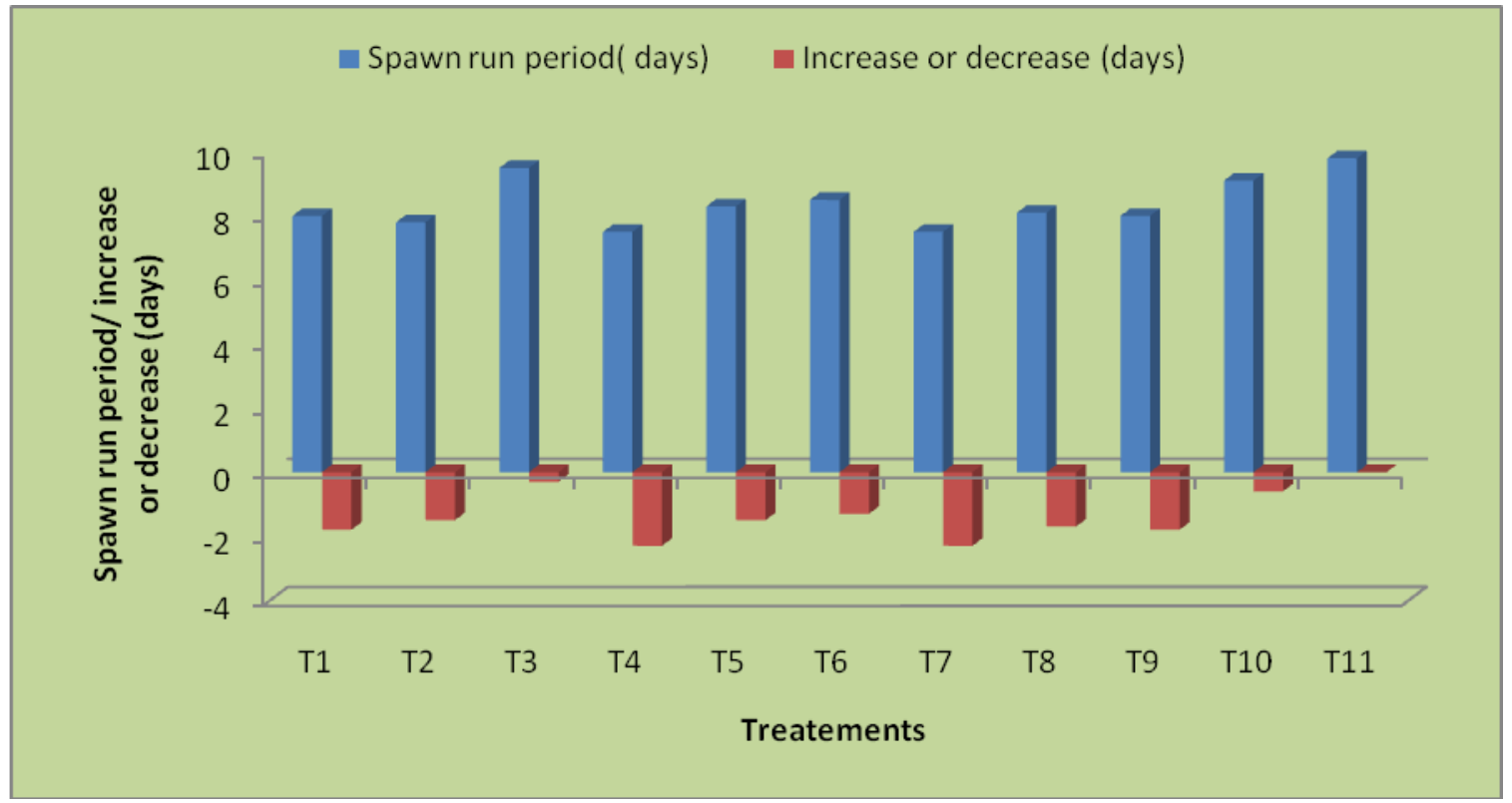

Novaluron 10 EC @ $0.5 \mathrm{ml}$ and chlorpyrifos 20 EC 4 ml (7.3 days), achook 1500 ppm @ 4 ml, nimbecidine 300ppm@5 ml, hot water treatment at $80-90^{\circ} \mathrm{C}$ for 10 and 20 minutes (7.6 days), novaluron 10 EC @ $1.0 \mathrm{ml}(8.0$ days) and @ $1.5 \mathrm{ml}$ (8.3 days) had significantly less spawn run time as compared to control (9.6 days) whereas it was at par with neem seed kernel extract $2 \mathrm{ml}$ (9.3 days) and hot water treatment at $80-90^{\circ} \mathrm{C}$ for 30 minutes ( 9 days). There was decrease in spawn run time of 2.3 days both in chlorpyrifos 20 EC @ $4 \mathrm{ml}$ and novaluron 10 EC @ $0.5 \mathrm{ml}$ followed by ml (2 days) in nimbecidine 300 ppm @ $5 \mathrm{ml}$ as compared to control (Fig. 1). Comparing the pooled mean value of both the season August 2013 and April 2014 revealed that the mean spawn run time of 7.5 days was recorded both in novaluron and chlorpyrifos which was at par with other treatments such as achook 1500 ppm @ 4 ml (7.8 days), nimbecidine 300 ppm @ $5 \mathrm{ml}$, hot water treatment at $80-90^{\circ} \mathrm{C}$ for 20 minutes (8.0 days) and novaluron 10EC @ $1.0 \mathrm{ml}$ (8.3 days). These findings are in accordance with Aggarwal (2000) and Shivanna (2001) had observed that nimbecidine $300 \mathrm{ppm}$ reduced the spawn run period as compared to control. Kumar (2004) also noticed that incorporation of achook $1500 \mathrm{ppm}$ also reduced spawn run time. Shivanna (2001) and Mandeep (2002) also observed the delayed spawn run period by the application of neem seed kernel extract powder. Neem seed kernel extract @ $2 \mathrm{ml}$ (9.5 days) and hot water treatment at $80-90^{\circ} \mathrm{C}$ for 30 minutes (9.1 days) were at par with the control (9.8 days). This study is corroborated with Kumar (2005), who also reported that spawn run period was longer in all the botanical treatments over control as the maximum inhibition (0.33 days) was in sarpgandha treatment. Comparing the data in term of increase or decrease in spawn run time, there were decrease in spawn run time in all treatments, however, maximum decreased in spawn run time (2.3 days) was recorded in novaluron $10 \mathrm{EC} @ 0.5 \mathrm{ml}$ and chlorpyrifos 20 EC @ $4 \mathrm{ml}$ as compared to control (Table 1).

In conclusion, the mean spawn run time of 7.5 days was recorded both in novaluron $10 \mathrm{EC}$ @ $0.5 \mathrm{ml}$ and chlorpyrifos 20 EC @ $4 \mathrm{ml}$ 
which was at par with other treatments such as achook 1500 ppm @ 4 ml (7.8 days), nimbecidine 300 ppm @ $5 \mathrm{ml}$, hot water treatment at $80-90^{\circ} \mathrm{C}$ for 20 minutes $(8.0$ days) and novaluron 10EC @ $1.0 \mathrm{ml}$ (8.3 days). Neem seed kernel extract @ 2 ml (9.5 days) and hot water treatment at $80-90^{\circ} \mathrm{C}$ for 30 minutes (9.1 days) were at par with the control (9.8 days). It may concluded that the

\section{Acknowledgement}

The first author gratefully acknowledges Department of Agricultural Entomology and Department of Plant Pathology, Choudhary Charan Singh Haryana Agricultural University, Hisar, Haryana for providing institutional infrastructure facilities to conduct experiments. Author also thankful to Dr. O. P. Ahlawat, DMR, Solan for providing strains of paddy straw mushroom.

\section{References}

Aggrawal, A. 2000. Occurrence of mushroom flies and biology of phorid fly, Megaselia sandhui (Disney) on white button mushroom, Agaricus bisporus (Lange) Singer. M.Sc. Thesis, CCS Haryana Agricultural University, Hisar.

Ahlawat, O. P. and Tewari, R. P. 2007. Cultivation technology of paddy straw mushroom (Volvariella volvacea) 2007. National Research Centre for MushroomICAR, Chambaghat, Solan -173213 (HP):144.

Ahlawat, O. P., Kumar, P., Rai, R. D. and Tewari, R. P. 2006. Variation in biochemical properties of different strains of Volvariella volvacea Bull Fr Singh under different condition. Indian Journal of Microbiology, 46(1): 31-37.

FAOSTAT. 2016. http://www.fao.org/faostat/ en/\#data Retrieved 2017. 4-28.

Kumar, P. 2005. Screening of white button mushroom, Agaricus bisporus (Lange) Singer strains against mushroom flies and their management through botanicals. M. Sc. Thesis, CCS Haryana Agricultural University, Hisar.

Kumar, V. 2004. Studies on mushroom flies on white milky mushroom, Calocybe indica (Purkayastha and Chandra). M.Sc. Thesis, CCS Haryana Agricultural University, Hisar.

Li, G. S. F. and Chang, S. T. 1982. Nutrition values of Volvariella volvacea In: S. T. Chang and T. H. Quimio. (Eds.) Tropical mushroom: Biological nature and cultivation Methods. The Chinese University Press, Hong Kong, 1982, 199-219.

Mandeep, 2002. Studies on the management of mushroom flies on white button mushroom, Agaricus bisporus (Lange) Singer M. Sc. Thesis, CCS Haryana Agricultural University, Hisar.

Sharma, V. P., Annepu, S. K., Gautam Y., Singh M. and Kamal S. 2017. Status of mushroom production in India. Mushroom Research. 26(2): 111-120.

Shivanna, B. 2001. Biology and management of sciarid fly, Bradysia tritici (Coquillet) on white button mushroom, Agaricus bisporus (Lange) Singer, M.Sc. Thesis, CCS Haryana Agricultural University, Hisar.

Singh, K., Dey, I. and Shrvan, K. 2018. Paddy Straw Mushroom (Volvariella spp.): A Natural Scavengers who help in Malnutrition and Environment Protection. International Journal of Microbiology Research. 10(5): 1183-1185.

\section{How to cite this article:}

Gaikwad Mahesh Balaso, Krishan Kumar Mrig, Surjeet Singh, Challa Nalini and Panma Yankit. 2019. Effect of Different Treatments on Spawn Run Time of Paddy Straw Mushroom, Volvariella volvacea. Int.J.Curr.Microbiol.App.Sci. 8(03): 1713-1717. doi: https://doi.org/10.20546/ijcmas.2019.803.199 